УДК: 1(091).

ВОЛОДИМИР ПЕТРУШОВ

доктор філософських наук, професор, Украйнський державний університет залізничного транспорту (м. Харків, Україна)

ORCID: 0000-0003-3279-2180

ВІТАЛІЙ ПАВЛОВ

кандидат філософських наук, доцент,

Український державний університет залізничного транспорту

(м. Харків, Україна)

\title{
ВІД СТРУКТУРНОЇ ЛІНГВІСТИКИ ДО СЕМІОЛОГІЧНОЇ ФІЛОСОФІЇ: ІСТОРИКО-ФІЛОСОФСЬКИЙ АНАЛІЗ
}

У статті показана еволюція поглядів щодо тлумачення мови, як універсального методу, який так чи інакше впливає на філософський дискурс. Відмічено, що вже у надрах структурної лінгвістики (Ф. де Соссюр, Р. Якобсон та ін.) сформувався семіологічний підхід дослідження мови, що заклав умови для подолання методологічного суб'єктивізму попередньої науки та філософії. Підкреслено, що мовна структура $є$ не просто пояснювальною конструкцією; вона, виокремивши у собі множину певних метафізичних опозицій, прагне подолати їх та вийти за межі емпіричних досліджень. За іï допомогою виникає можливість розглядати психічні i духовні феномени як такі, що не виводяться каузально з фізіологічних процесів, а навпаки, «внутрішньо запрограмовані», тобто створюють певні структури (Е. Гуссерль), що спричинює виникнення різноманіття грандіозних спекулятивних теорій у блоці гуманітарних наук, які прагнули наукової суворості та оновлення власної методологічної рефлексії, апелюючи до систематичності та об’єктивізму структурної лінгвістики закладаючи тим самим засади семіологічної філософії. Охарактеризовано особливості семіологічної філософії, а саме: зародження діадичних та тріадичних моделей структуралістів i постструктуралістів 3 їх репрезентативністю часово-просторових опозицій; неможливість хронологічного розрізнення структуралізму та постструктуралізму та їх поєднання у єдиний спосіб філософування; пропонування концептуального апарату пошуку нової форми раціональності (т. зв. «формальної раціональності»), яка припускає безліч актуалізацій у «вербальному психоаналізі» (Ж. Лакан), літературознавстві (Р. Барт), «структурної епістемології» М. Фуко, антиметафізичних демаршах Ж. Деріда і Ж.-Ф. Ліотара та спробах «симулякризації дійсності» Ж. Бодрійяра.

Ключові слова: мова; мовлення; мовна структура; структурна лінгвістика; семіологічна філософія; семіологічний знак; знакова система; метафізична опозиція

Постановка завдання та аналіз останніх публікацій. Філософське осмислення мови $є$ досить традиційною темою, яка висвітлювалася ще в античні часи. Проте, справжній «лінгвістичний поворот» у філософії відбувся в кінці XIX - на початку XX століть і був зв'язаний з іменем швейцарського лінгвіста Ф. де Сосюра та його послідовників, що вимагали найскорішого відходу від традиційного розуміння мови як відповідності слів речам. Вони стверджували, що окрім аналізу мови як носія смислу існує ще й інший, «завуальований» ii аналіз, який долає межі цього смислу і розглядає мову, як даність, що не залежить ані від промовця, ані від речей навколишнього світу: сенс існує лише там, де є система знаків. 
Ф. де Сосюр у «Курсі загальної лінгвістики» описує підвалини семіології нової «науки про знаки, котра вивчає, що здійснюється, коли людина робить спробу передати свою думку за допомогою засобів, які неодмінно носять умовний характер» (Соссюр, 1990, с. 196). В авторському розумінні ця умовність тлумачиться як довільність мовного знаку, тобто повна незалежність означника від означуваного. Сема (або семіологічний знак) - умовний знак, що $\epsilon$ частиною певної знакової системи. Він $є$ вторинним по відношенню до системи, існує завдяки поєднанню фонізму й значення, але тільки у контексті кореляції з іншими елементами системи. Іншими словами, між семіологічними знаками не існує речового зв'язку; мовна діяльність не регулюється певними людськими нормами, а людський розум не корегує і не спрямовує мову: вона, скоріше, має певну несвідому психологічну мотивованість.

Примат системи семіологічних знаків над кожною окремо взятою семою Сосюр яскраво інтерпретує на прикладі грошової системи: певний знак на паперовому або металевому носії постає грошовим, якщо раніше склалася грошова система, котра не тільки визначає номінали цих знаків, але і констатує певні правила дій з ними (порядок грошових операцій, шляхи обміну грошей на товари тощо). Поза грошовою системою грошовий знак руйнує своє змістовне навантаження: він перетворюється на безглуздого паперового або металевого носія певних символів. Якщо ж казати про значущість грошової системи, то вона розкривається на кшталт «лінгвістичної цінності», сутність якої Ф.де Сосюр розкриває так: «Цінність в кожний момент свого існування повністю синонімічна певному члену, що входить до системи подібних йому членів, і в кожний момент свого існування вона повністю синонімічна предмету обміну. Якщо розглянути, з одного боку, предмети обміну, а 3 іншої - члени, що утворюють систему, то між ними не існує жодної збіжності. Властивістю цінності є здатність співвідносити ці два роди речей» (Соссюр, 1990, с. 193).

Другою проблемою, до якої апелювала семіологія, стала проблема співвідношення мови (langue) і мовлення (parole). Взагалі кажучи, Ф.де Сосюр добре розумів, що мова, за своєю природою, є однорідним явищем, системою знаків, що поєднує у собі зміст й акустичний образ. В той же час мовлення явище різнорідне. Якщо мова - це готовий соціальний продукт, що пасивно реєструється промовцем, то мовлення є його суто індивідуальним актом волі i розуму. Звідси випливає не тільки наявність відмінності між мовою та мовленням, але й необхідність їх протиставлення. Щоб підкреслити наявність опозиції langue-parole, Сосюр неодноразово застосовував у «Курсі загальної лінгвістики» вислів «на противагу». Цей факт спричинив у більш пізніх філософських дослідженнях (наприклад, у постструктуралізмі) повне протиставлення мови мовленню. Стало зрозумілим, що промовець використовує семіологічні мовні знаки з метою виразу свого наміру, проте межі їх використання у мовленні визначаються не ним, а системою мови (langue), яка створює умови сенсу дискурсу. Протиставлення langue-parole заклало підгрунтя побудов діадичних та тріадичних моделей структуралістів i 
постструктуралістів, а реалізацію мовної діяльності почали позначати неоднозначним і багатогранним терміном langage.

Обгрунтовуючи лінгвістичні співвідношення «мова-мовлення» та «означник-означуване», Ф. де Сосюр, а трохи пізніше - і Р. Якобсон -дістають висновку про контрастність синхронічної та діахронічної систем, що виражає вимогу визначення структури мови, абстрагуючись від іï розвитку. Структуральний метод розглядає мову як систему знаків. Будь-яке слово, що включене в цю систему, виявляє власну повноту не шляхом дослідження його історії, а шляхом вияву його співвідношень 3 іншими елементами системи словами. Взята в певному зрізі і в певний момент існування, мова, як система, утворює сукупність взаємозалежних елементів - його складових, i являє синхронічний вимір системи. Навпаки, всі попередні стани мови, співвіднесені 3 ii теперішнім станом, являють собою діахронічний вимір системи, або їі історію. Тим самим лінгвісти дістають висновку про можливість подвійного управління мовних знаків в контексті опозиції «синхронія-діахронія мови». У першому випадку опозиції закріплені суспільством, соціально пасивні і не залежать від індивіду, а в другому - цілком підкоряються індивідуальній фонації, яка діє через призму волі і може припускати нескінченне різноманіття фонетичних варіантів, але з певним синхронічним обмеженням.

Виходячи $з$ цієї знакової природи мови, Ф. де Сосюр і Р. Якобсон дістають висновку, що мова $є$ найважливішою з усіх знакових систем, що існують, а тому може інтерпретувати всі інші семіотичні системи, в тому числі нелінгвістичні, починаючи від обміну знаками у тваринному світі і закінчуючи наукою, релігією, різноманітними проявами культури (живописом, музикою, тощо). Іншими словами, всі не-мовні знакові системи стають зрозумілими людині, якщо вони перекладаються на мову людського слова.

Перші уявлення про поняття структури і функції можна знайти у тезах, відредагованих Празьким лінгвістичним гуртком для першого Конгресу філологів-славістів. До цього гуртка входили чеські (В.Матезіус, Я.Мукаржовський, Б.Гавранек та ін.) і російські (Н.Трубецькой, Р.Якобсон) учені-мовознавці, які обгрунтували необхідність розглядати мову не лише як структуральну, а скоріше як функціонально-структуральну систему (Якобсон, 1985, с. 405). Саме ці тези вперше ввели в науковий побут вираз «закони структури лінгвістичних систем». Дослідниками в мові виділялося декілька протилежних аспектів, таких як антитеза синхронії та діахронії, з одного боку, i структури як системи абстрактних відношень та іiі реалізації в конкретному мовному матеріалі - 3 іншого. Базуючись на цих положеннях, вдалось вдосконалити уявлення про мовну систему. Тепер під мовою почали розуміти універсальну множину елементів, що виявляють свою єдність як на внутрішньому, так i на зовнішньому рівнях. На внутрішньому - це упорядкованість, взаємозв'язок мовних елементів, на зовнішньому - істотна спільність їх функціональних відношень у різних видах взаємодії.

Виклад основного матеріалу. Виявлення й інтерпретація мовної структури, або, інакше кажучи, «прагнення до адекватності, що пояснює», 
з’являється у лінгвістиці завдяки Романові Якобсону, який запозичив термін «структура» у американського дослідника Уітні. Саме якобсонівське розуміння структури як відображення сукупності відношень між мовними елементами, що розглядаються за способом їх зв’язку, спричинило виникнення пропозиції про існування законів структури, які існують так само, як закони еволюції. Іншими словами, синхронічні властивості мови, що є первісними, містять у собі певні функціональні відношення, які, в свою чергу, корегуються мовним носієм (тобто людиною) i, як наслідок, викликають мовну еволюцію.

Як на наш погляд, цей висновок Р. Якобсона $є$ цілком виваженим. Оскільки структура мови як спосіб зв'язку елементів детермінована внутрішніми і зовнішніми обставинами, вона є тим, що залишається відносно постійним, зберігається у поточному, мінливому мовному бутті. Втім, у процесі взаємодії елементів, що створюють цілісну мовну систему і самої системи 3 іншими матеріальними утвореннями (наприклад, з людиною), виникають зміни в елементах і системі в цілому. В міру накопичення цих змін змінюються функції окремих елементів i самої системи. Зміна функцій поступово призводить до зміни структури мови як цілісності і переходу їі на новий щабель розвитку.

Таким чином, якщо структура - це стале у мові, то функція виражає рух, мовну зміну. Отже, стосовно мови функціональність треба розуміти як відношення мовних структур до їхнього вживання. 3 цього приводу в колективних тезах, наданих IV з'їзду славістів Б.Гавранеком, К.Горалеком, В.Скалічкою і П.Тросом, підкреслювалося: «Представники Празької школи вважали найважливішою рисою мовних систем їхнє функціональне призначення, практичне використання мови (курсив наш - авт.)» (Эрлих В., 1996, с. 15). Інакше кажучи, другим кроком після опису синхронічного стану системи повинне стати обгрунтування шляхів переходу īi в наступний, діахронічний стан, тобто дослідження історії.

Безумовно, Р. Якобсона треба віднести до раціоналістичних лінгвістів, які традиційно починали свої роздуми про сутність діахронічного підходу з аналізу сосюрівської тези про те, що головною задачею лінгвістики є дослідження «фонологічної», «граматико-синтаксичної» або «семантичної» системи «природної» мови (langue), на відміну від «мовлення» (parole, speech) і від «мовленнєвої здатності» (faculté de langage). Але Якобсон розвинув і уточнив попередню інтерпретацію мови як синхронічної і діахронічної цілісності i виявив іiі універсальну суттєвість. Саме тому пошуки раціональності в історії мови можна відчути в усіх його роздумах. Наприклад, у роботі «Зауваження щодо фонологічної еволюції російської мови» Р.Якобсон наголошує на раціональному зв’язку діахронії з синхронією, що дає йому змогу обгрунтувати мовну здатність до саморегуляції: «У разі порушень мова намагається підтримати i відновити чистоту та гнучкість не лише словника, а й безпосередньо фонологічної системи, інструменту диференціації слів... Мова впродовж еволюції розв'язує внутрішні проблеми. Було би хибним уявляти собі 
лінгвістичну систему, полишену на саму себе, приреченою на стагнацію та незмінність» (Якобсон Р., 1999, с. 214).

Цілком зрозуміло, що мовна система може бути проінтерпретована як сукупність фактів, що грунтуються на логічних, раціональних законах, оскільки мова завжди структурна. Отже, зміна мови у контексті сосюрівського розуміння діахронії - це завжди лише зміна певних мовних фактів, яка детермінована раціональними законами. Втім, Р.Якобсон, аналізуючи фонологію мови, йде значно далі: він пропонує під сутністю діахронічного підходу розуміти не дослідження історії певних мовних фактів, а дослідження історії еволюції мовної системи як цілого.

На думку Р. Якобсона, вирішальнім фактором, який спричиняє еволюцію мови, стає свідомість спільноти суб'єктів-мовців. Саме вона утворює початкові умови, без яких неможливе мовлення. Але в той же час свідомість зводить нанівець «нездоланні бар'єри» між синхронією і діахронією, які були відправною точкою у роздумах женевських лінгвістів. Ось як Р. Якобсон обгрунтовує цю точку зору: «Предметом синхронічної лінгвістики не є факти, сприйняті спільнотою суб'єктів-мовців як одночасні для них, а є факти, одночасно сприйняті ними, тобто такі, що конституюють в даний момент зміст лінгвістичної свідомості. Свідомістю суб'єктів-мовців одні з цих фактів можуть бути тісно асоційовані 3 теперішнім, інші ... можуть бути віднесені до минулого, а також тяжіти до майбутнього. Антиномія, що існує між синхронічною і діахронічною характеристиками фонічної матерії мови буде зруйнована тієї миті, коли зміни розглядатимуться у зв'язку з фонологічною системою, якій вони підпорядковані. Історична фонетика перетворилася б, таким чином, на історію еволюції фонологічної системи».

Вважаємо, що саме в цьому контексті лінгвіст вводить вираз «закони структури лінгвістичних систем», причому провідне місце у лінгвістичній системі, на його погляд, займає фонологія мови, оскільки вона будується на засадах логічних зв'язків, що не просто продукуються історією, а є більш сильними, вагомішими. Історія мови може лише сказати про те, у якому вигляді актуалізується мовна система в певний проміжок часу, виокремити особливості цієї системи у порівнянні з іншою історичною добою існування мови. Коли ж Р. Якобсон говорить про фонологічні особливості, то має на увазі ті зв'язки, що здатні перебудувати ияіле системи, ступінь свободи якого корегується законами структури, визначеними Ф.де Сосюром. «Змінність типів структури фонологічної системи, - пише Р. кобсон з цього приводу, - обмежена так само, як і змінність типів структури морфологічної та синтаксичної систем, а також, ймовірно, і множина типів зв’язків між фонологічною, морфологічною та синтаксичною системами. Визначаючи закони загальної фонології, ми дістаємо можливість контролювати ефективні спроби реконструкції фонічного характеру будь-якої мови в ту чи іншу історичну добу» (Jakobson R.,1961, c. 248).

Цей висновок нескладно зрозуміти, оскільки фонологічна мовна система складається 3 суто опозитивних сутностей. У відповідності 3 логічною 
природою опозиції, кожна фонологічна ознака не може існувати ізольовано, $\mathrm{i}$ завжди спричиняє наявність в цій мовній системі протилежної ознаки (наприклад, переривчатість-непереривчатість звучання, короткість-довгота звуку, тощо). Отже, подвійність членів опозиції не є довільною, вона необхідна, тобто підкоряється логічним законам. Звідси констатуємо: фактор довільності у фонологічної системі значно обмежений.

Відтак, Р.Якобсон робить спробу пом'якшити сосюрівську опозицію між діахронією і синхронією за допомогою категорії «структура». Він підкреслює, що системний підхід виявляється не менш важливим в діахронії, ніж в синхронії: «сосюрівська доктрина мови, розглядувана як система, дає необхідні засновки для теорії мови як синхронічного явища, проте вона продовжує приписувати цій системі випадкове походження, вона i далі розглядає діахронію як агломерацію змін акцидентального походження. Теорія мовної діахронії можлива тільки у вигляді дослідження мутацій структури та структури мутацій» (Якобсон Р., 1999, с. 216). Іншими словами, кожний мовленнєвий акт і кожне мовне явище - від фонеми до творів словесного мистецтва - так чи інакше входить в двоякі часові рамки: лінійну послідовність 3 одного боку, та точну одночасність з іншого боку. В цьому і сила, і відносна обмеженість мови як засобу вираження.

До речі, Р.Якобсон неодноразово вказував на намагання Ф. де Сосюра ототожнити синхронію зі статикою, а діахронію з динамікою. Він погоджується 3 тим, що існують статичні стани, які простягаються в часі; але мають місце й динамічні стани, які виявляються на рівні синхронії як взаємодія різноманітних субкодів. Отже, кожна мовна структурна комбінація (певний структурний зріз мови) здійснюється в часовому вимірі. Лише в цьому можна розглядати примат діахронії над синхронією.

Швейцарський дослідник Е. Голенштайн, відзначає, що нова, якобсонівська концепція мови, що зробила спробу ліквідувати «нездоланні бар'єри» між синхронією і діахронією за допомогою запровадження поняття структури, отримала право на життя під впливом феноменології Е. Гуссерля, вирішальне значення якої для структуралізму можна порівняти лише 3 вагомістю «Курсу загальної лінгвістики» Ф. де Сосюра. Саме Е. уссерль зробив спробу обгрунтувати, що психічні i духовні феномени не $є$ фіксованими, даними раз і назавжди. Вони не виводяться каузально з фізіологічних процесів, а навпаки, «внутрішньо запрограмовані», тобто створюють певні структури. «Ми не ведемо тут розмову в термінах історії, - зауважував філософ. - У цьому посиланні на первісність немає й не може бути необхідності в будь-якій думці про генезу вздовж лінії психологічної каузальності або еволюційної історії» (Холенштайн Э.,1996, с. 7). Тим самим він не тільки подолав психологізм, але й зробив виклик поглядові філософії історії, за яким історія осягається як генеза, де більш раціональне випливає 3 менш раціонального, i де взагалі щось «більше» завжди виводиться 3 чогось «меншого». У цьому розумінні атемпоральність об'єктивного предметного смислу є неприступною для того, щоб емпірично породжувати наближення до осягнення цього смислу. Реально 
суще співвідноситься з сутністю як випадкове з необхідним, оскільки кожній сутності властиве своє поле окремих випадків, котрі можуть траплятись в той чи інший час, в різних просторових ділянках, але їх сутнісні характеристики залишаються незмінними. Подібна тенденція до сприйняття змін сущого породжується завдяки здійсненню основоположної для феноменології операції трансцендентальної редукції. За допомогою цього методологічного засобу свідомість позбавляється наївності, або природничої установки, яка полягає в твердому переконанні, що світ, який є тут і тепер, є просто даним. У наслідку редукції трансцендентальна свідомість корегує себе і з'ясовує, що вона сама $є$ такою, що надає буттю значення. «Певним чином і з певною обережністю у слововжитку ми можемо також сказати, - зауважує Гусерль, - що всі реальні єдності є «смисловими єдностями». Смислові єдності передбачають (як я знову підкреслюю: не внаслідок того, що ми можемо дедукувати це 3 тих чи інших метафізичних постулатів, а тому, що ми можемо показати це завдяки споглядальній, цілком безсумнівній процедурі) смислонадавальну свідомість, котра, зі свого боку, існує абсолютно, а не завдяки іншому смислонадаванню» Husserl E., 1913, с. 106).

Виходячи 3 аналізу філософської спадщини Е. Гуссерля, нескладно 3'ясувати, що відзначені Р. Якобсоном панхронічні мовні закономірності, які водночас охоплюють синхронічні i діахронічні особливості мови, мають феноменологічне походження, а отже, пов'язані з лінгвістичною свідомістю. Інакше кажучи, якобсонівська лінгвістична концепція базується на т. зв. «феноменологічному» принципі, згідно з яким мовний об'єкт досліджується не сам по собі, а у зв'язку з тим, як його спостерігає і сприймає суб'єкт (Иванов В. В., 1985, с. 7).

Тут, передусім, йдеться про розроблену Р. Якобсоном теорію мовленнєвого акту комунікації, яка заслуговує на особливу увагу у світлі повороту у XX столітті від філософії свідомості до філософії комунікації, проілюстрованого в роботах М. Бубера, Ю. Габермаса, М. Гайдеггера та ін. визнаних мислителів.

Модель мовленнєвої комунікації Якобсона складається з шости складових: адресанту, адресату, контексту, повідомлення, контакту і коду. Кожна з них може виконувати шість функцій: денотативну (або когнітивну), емотивну (або експресивну), конативну, фатичну, метамовну та поетичну. Адресант посилає повідомлення адресату. Для того, щоб повідомлення могло виконати свої функції, необхідний контекст, який однозначно сприймається адресатом. Нарешті, для здійснення акту комунікації треба забезпечити наявність контакту, тобто необхідного фізичного (наприклад, вербального) каналу i психологічного зв'язку між адресантом й адресатом і користуватись хоча б частково загальним для них кодом (зрозумілим принципом кодування i декодування інформації) Якобсон Р., 1975, с. 198).

Р. Якобсон цілком справедливо вважає, що особлива роль в низці складових мовленнєвого акту належить повідомленню. Втім, будь-яке повідомлення, як правило, виконує декілька функцій. А отже, знакова 
структура одного і того ж повідомлення (тобто синхронічна складова розмовної мови) може приймати різні значення в залежності від функції, яка переважає.

Функціональна модель мовленнєвої комунікації Р. Якобсона характеризує зміну мови як цілого, причому ця зміна розкривається у контексті системного підходу. «Різноманітні функції мови, - пише дослідник, - тісно зв’язані між собою, i пермутації функцій неперервні. Принцип рівноваги і одночасна тенденція до його порушення являють собою невід'ємні властивості мовного цілого» (Якобсон Р., 1985, с. 132). Так, денотативна функція мови безпосередньо несе інформацію про предмет повідомлення; емотивна функція виражає відношення адресанта до предмета мовлення шляхом висловлення іронії або гніву, надаючи тим самим додаткову інформацію до денотату повідомлення. Нарешті, конативна функція надає повідомленню запитальну, окличну або наказову форму, забезпечуючи тим самим певний акцент інформації повідомлення.

Безперечно, наведена тріада функцій підпорядковується лінгвістичному аналізові, оскільки «було б вкрай небезпечним спрощенням переоцінювати роль статичного фактору у розвитку мови... Низька частота i незначне функціональне навантаження тієї чи іншої фонологічної відмінності, звичайно, сприяють їі втраті... Встановивши наявність низки мутацій, що виникли в один i той же час, ми повинні піддати аналізові всю в'язку мутацій як ціле. Зв'язок між такими мутаціями не може бути випадковим; всі вони щільно пов'язані між собою» (Якобсон Р., 1985, с. 126, 128).

Особливої уваги заслуговують фатична, метамовна і поетична функції мовленнєвого акту, які на перший погляд мають допоміжне значення. Втім, ними також не можна нехтувати, оскільки «...необхідно розглядати звукові зміни у зв’язку з різнофункціональними звуковими системами. Але історична фонологія не вичерпується лише описом мутацій. Перед нами постає задача інтерпретації цих мутацій» (Якобсон Р., 1985, с. 130).

Фатичну функцію виконують особливі повідомлення, які вказують на прагнення вступити в комунікацію, тобто спрямовані безпосередньо на налагодження контакту між адресантом i адресатом. Загальна мета таких повідомлень - підтримання комунікації за допомогою діалогів, встановлення низки настанов тощо (Якобсон Р., 1975, с. 201).

Метамовна функція певних повідомлень, або функція тлумачення розкривається тоді, коли останні використовуються для 3'ясування правил коду, що уможливлюють ймовірність комунікації між адресантом і адресатом. Зазвичай код встановлюється на самому початку спілкування i міцнішає внаслідок застосування первісних навичок говоріння. Він завжди має власну множину підкодів, себто функціональних варіантів мови, що характеризують стилі мови, розбіжності між формальним і неформальним мовленням, порядок здійснення монологу, діалогу і дискусії, граматичні і лексичні правила тощо. Розглядаючи цю функцію, Р. Якобсон тлумачить іii у вигляді засобу представлення інформації в формі, придатній для іiі передачі по каналах зв’язку. «Система розрізняльних ознак - відзначає він, - являє собою ефективний $\mathrm{i}$ 
економічний код: кожна ознака - це бінарна опозиція наявності і відсутності будь-якої характеристики. Вибір і взаємодія розрізняльних ознак в будь-якій мові виявляють дивну регулярність. Комунікативна релевантність розрізняльних ознак, що основана на їхній семантичній значущості, виключає будь-які випадкові явища в їхній структурі. Інвентар розрізняльних ознак, що існують у мовах світу, гранично обмежений, а сумісність ознак в межах однієї мови обмежується загальними імплікативними законами».

Під поетичною функцією Р. Якобсон розуміє не просто функцію словесної майстерності, a, скоріше, комплекс процедур, який дозволяє посилити відчуття знаків, поглибити дихотомію між знаками і предметами. «Яким би рівнем структури вірша не займався дослідник, - констатує він, - йому терміново приходиться стикатися 3 взаємозв'язком інваріанта і варіантів... Віршова форма - одна з найважливіших особливостей поетичної мови; тому неможливо до кінця зрозуміти жодне правило метру (моделі вірша - авт.) не з'ясувавши для себе головного питання - яка функція цього правила в мистецтві слова». Отже, поетична функція нівелює, але завжди враховує низку інших функцій, про які йшлось вище. Тому, вивчаючи поетичну функцію, лінгвісти не можуть обмежуватися лише поезією. Поетична функція припускає інтровертивне відношення до вербальних знаків як до єдності означника і означуваного і саме тому $\epsilon$ домінантою в поетичній мові. Всякий витвір мистецтва порушує початковий мовний код, спонукає адресата до його ревізіі, відкриваючи тим самим раніше невідомі або забуті можливості. Нарешті, «поетична функція збуджує мову подолати автоматизм і невідчутність слова, що також веде до зміщень у фонологічній структурі» (Якобсон Р., 1985, с. 132). Внаслідок цього перед адресатом повідомлення постає новітня мовна реальність, в світлі якої по-новому осмислюється вся мова та її можливості.

Функціональний аналіз акту мовленнєвої комунікації Р. Якобсон називає «інтегральним методом», що дозволяє описати мовні зміни. Причому «опис дає нам матеріал, який має відношення до двох мовних станів - стану до мутації i стану після мутації, - i дозволяє порушити питання про напрямок і смисл мутації. Як тільки це питання поставлено, ми переходимо зі сфери діахронії в сферу синхронії» (Якобсон Р., 1985, с. 130). А отже, розглядаючи зміну мовної системи у часі, ми так чи інакше підпорядковуємо іiі законам лінгвістичної синхронії, переводимо у площину телеологічних проблем. Втім, слід пам'ятати, що «спроби ототожнити, 3 одного боку, синхронію, статику i сферу застосування телеології, а з іншого - діахронію, динаміку і сферу механічної причинності, неправомірно звужують рамки синхронії, перетворюють історичне мовознавство на конгломерат розрізнених фактів і складають примарну і шкідливу ілюзію про безодню, що розділяє проблеми синхронії і діахронії» (Якобсон Р., 1985, с. 132). Причому єдність мовної синхронії і діахронії проявляється, згідно з Якобсоном, в тому, що «закони структури лінгвістичних систем» у першому випадку пов’язані з певною структурою, а в другому - $з$ апріорі заданою мовленнєвою моделлю. 
Закономірним наслідком подальшої реалізації цих лінгвістичних висновків постало виникнення у середині XX століття у Франції так званої «семіологічної філософії». Ї̈̈ витоки беруть початок у блоці гуманітарних наук (антропології, психології і поетиці), які прагнули наукової суворості та оновлення власної методологічної рефлексії, апелюючи до систематичності та об’єктивізму структурної лінгвістики. Вперше цей термін до філософського побуту ввів у роботі В. Декомб, зазначивши, що «семіологічна філософія не представлена в якійсь певній праці. Вона, швидше, є тенденцією, що зовсім не обмежується одним автором або самими професійними філософами. Ця філософія безумовно $\epsilon$ філософією мови, бо вона намагається розвинути всі філософські наслідки факту, на який звернули увагу деякі антропологи та лінгвісти: знак може бути зрозумілим лише всередині системи» (Descombes V., 1983, с. 96).

Спроби визначити семіологічну філософію та їі особливості знаходимо у монографії української дослідниці О. Йосипенко, яка пише, що «семіологічна філософія є філософією мови, що акцентує увагу на лінгвістичному вимірі філософської рефлексії і прагне переформулювати традиційні філософські проблеми $з$ урахуванням їхньої мовної складової. Віра в те, що дослідження мови $є$ ключовим у модернізації філософського дискурсу та соціальних наук, споріднює ï з деякими напрямами аналітичної філософії, різноманітними напрямами лінгвістики та деякими тенденціями в антропології, соціології $\mathrm{i}$ психології початку та середини XX століття» Йосипенко, 2012, с. 94). Втім, переважну значущість цієї філософії для історії світової філософської думки дослідниця вбачає, насамперед, не в тому, що вона являє собою певний філософський напрям, а навпаки, в тому, що вона інтерпретує конгломерат різноманітних (іноді ворожих) філософських течій та тенденцій на підвалинах семіології Ф. де Сосюра та його послідовників. Погоджуючись з В. Декомбом і в черговий раз підкреслюючи влучність назви «семіологічна філософія», О. Йосипенко заявляє, що вона «...вказує на мовне підгрунтя цієї філософії, а саме - на семіологію, яка вивчає знакові системи в різних галузях соціального життя та орієнтується на мову як зразкову семіологічну систему» Йосипенко, 2012, с.77). На думку дослідниці, семіологічне уявлення про мову як знакову систему виступає не тільки підгрунтям для критики модерної метафізики (i, передусім, «філософії суб'єктивності»), але й «пропонує потужний концептуальний апарат для створення нової, «не-метафізичної» мови філософії» Йосипенко, 2012, с. 76).

Аналіз особливостей семіологічної філософії для нашого дослідження $\epsilon$ важливим 3 декількох причин. По-перше, саме у іiі надрах зароджуються діадичні та тріадичні моделі структуралістів і постструктуралістів 3 їх репрезентативністю часово-просторових опозицій, зокрема опозиції «синхронія-діахронія мови». По-друге, вона вказує на неможливість хронологічного розрізнення структуралізму та постструктуралізму і робить спробу їх поєднання у єдиний спосіб філософування, який об'єднує як представників структуралізму, так і представників постструктуралізму. Потретє, вона вимагає оновлення власне філософської рефлексії і не обмежується 
лише критикою модерної метафізики, але й пропонує концептуальний апарат пошуку нової форми раціональності (т. зв. «формальної раціональності»). Цей особливий апарат, що бере початок у лінгвістиці (Ф.де Сосюр, Р. Якобсон та ін.), згодом розгортається у багатьох гуманітарних науках: спочатку в антропології (К.Леві-Строс), дещо пізніше - у «вербальному психоаналізі» (Ж. Лакан), літературознавстві (Р.Барт), i, нарешті, лунає у філософській концепції «структурної епістемології» М. Фуко, антиметафізичних демаршах Ж. Деріда i Ж.-Ф. Ліотара та спробах «симулякризації дійсності» Ж. Бодрійяра.

О. Йосипенко виділяє низку особливостей семіологічної філософії, на яких має сенс зупинитись більш детально.

Нами підкреслено раніше, що саме у надрах структурної лінгвістики сформувався семіологічний підхід дослідження мови, який, на думку його ідейних батьків Ф. де Сосюра і Р. Якобсона, склав умови для подолання методологічного суб’єктивізму попередньої науки та філософії. Особлива значущість та новизна цього підходу полягала у підвищенні онтологічного статусу знаку: знак - це специфічний об’єкт, який не залежить від суб'єкту мовлення та існує виключно завдяки систематичному (внутрішньому) зв'язку власних складових - означника та означуваного. Руйнування цього систематичного зв’ язку неодмінно призводить до руйнування самого знаку.

Не залежить від суб’єкту мовлення й власне структура мови (langue). Вона регулює протікання мовних винаходів індивідів, що складають у власній сукупності мовлення (parole). Спосіб иi існування може бути лише теоретично описаний та конституйований у вигляді системи правил та можливостей їхньої реалізації. Тобто структура $є$ не просто пояснювальною конструкцією. Вона, виокремивши у собі множину певних метафізичних опозицій (наприклад, «звук-значення», «означник-означуване», «мова-мовлення», «синхроніядіахронія», тощо) прагне подолати їх, вийти за межі емпіричних досліджень, та спричиняе виникнення різноманіття грандіозних спекулятивних теорій на цьому підгрунті. Саме тому структуралізм увійшов у скарбницю світової філософії, передусім, як ім'я універсального наукового методу, що так чи інакше впливає на філософський дискурс.

Проте, унікальність структурального методу дослідження була значно перебільшеною внаслідок недостатньої методологічної проробки понять Сосюрівської та Якобсонівської лінгвістики власне іï авторами, в чому можна переконатись особисто під час роботи з першоджерелами. В ході аналізу цих робіт неодноразово доводиться стикатися 3 протиріччями в авторському тлумаченні різного роду дефініцій лінгвістичних понять та категорій. Як здається, саме з цих причин понятійний апарат лінгвістики семіологами доби структуралізму застосовується по-різному.

Наприклад, і у К. Леві-Строса, і у Ж. Лакана несвідоме, яке керує мовою, як повноважною складовою людської культури, піддається членуванню та раціональній впорядкованості за допомогою різноманітних виявів механізму функціонування безпосередньо мови. Іншими словами, в контексті праць цих авторів саме несвідоме постає об’єктом структуралістської формалізації. Але, 
якщо 3 точки зору К. Леві-Строса несвідомі відносини регулюють соціальне життя та $є$ предметом дослідження етнології (дослідженню піддається т. зв. колективне несвідоме), то у творах Ж. Лакана вони характеризують міжособові стосунки (досліджується переломлення суспільних відносин у площині індивідуальної психологіï), а тому $\epsilon$ предметом дослідження вербальної психології. Таким чином, попри усі позитивні наслідки цих структуралістських досліджень, останні яскраво демонструють наявність формалістичних припущень, які, хоча й будуються за принципами ізоморфізму між мовою та несвідомим, але певним чином долають межі науковості.

3 подібними проблемами прийшлось зіткнутись й М.Фуко при визначенні умов виникнення історичних епістем. Тому, критики структуралістських концепцій, яких можна відверто віднести до представників філософії мови, звертають увагу лише на роль «мовного каналу» у філософському дискурсі, користувачем, а не творцем якого постає філософ. Цей «мовний канал» функціонує на кшталт ретельно дослідженого Р. Якобсоном акту мовленнєвої комунікації з усіма його функціональними особливостями. О. Йосипенко справедливо зазначає 3 цього приводу, що «структуралізм виникає у дисциплінах, де, по-перше, головний предмет аналізу може бути представлений як сукупність «повідомлень», утворених згідно з певним кодом, по-друге, де сенс повідомлення не може бути пояснений апеляцією до свідомості мовця, а потребує встановлення коду (правил) комунікації» (Йосипенко, 2012, с. 103).

Пошуки у контексті структурної лінгвістики т. Зв. «формальної раціональності» уможливлюються завдяки розумінню мови як системи зі структурними відношеннями, що конституюються суворими правилами без участі суб'єкту і вже одержані ним у цілком сформованому вигляді. Ці структурні відносини накладаються на хаотичний та невпорядкований потік мовних установлень суб'єктів у процесі їх спілкування. Тим самим всі повідомлення, що так чи інакше припускають подібну формалізацію, підпадають під структурний аналіз. Тому, цілком справедливим стає висновок Ф. Валя, упорядника першого видання колективної збірки під назвою «Що таке структуралізм?» (Париж, 1968 р.), стосовно розуміння структуралізму. «...Скрізь, де знак ще не визнаний в його безумовно основоположній позиції, думка ще не зробила структурного кроку. Скрізь, де примат знаку вже спростований, знак зруйнований або реконструйований, думка вже вийшла 3 орбіти структуралізму» (Whal F., 1968, с. 304).

Втім, не зважаючи на те, що коріння семіологічної філософії занурюються у безодню лінгвістичного знання, іiі не можна ототожнювати зі структурною лінгвістикою. «Семіологічна філософія не $\epsilon$ філософським аналізом мовлення (виявленням способів означати, притаманних термінам та фразовим конструкціям), - пише О. Йосипенко. - Вона $є$ спробою уникнення «мови метафізики» та пошуком стратегій цього уникнення. Саме на такому шляху вона звертається до здійсненої структурною лінгвістикою критики традиційної (модерної) концепції мови та знака. Якщо остання передбачає, що знак $\epsilon$ субститутом речі, відсилає до чогось іншого поза собою (до «об’єкта» або 
«ідеї») і є «знаком присутності», то семіологічна філософія кладе край цьому підкоренню знаку чомусь поза ним самим. Згідно з семіологічною концепцією знаку, знак $є$ системним і означає лише всередині системи завдяки своїм відмінностям від інших знаків... Сенс, згідно з семіологами, є лише там, де $\epsilon$ система знаків, щоб зрозуміти сенс будь-якого значущого факту (не лише мовного), потрібно знайти систему, якій він належить» (Йосипенко, 2012, с. 79).

Але тут ми знову стикаємось 3 проблемою суб'єкта, котрий, базуючись на наївній вірі в людський розум, нібито повинен «відшуковувати» ту мовну систему, що надає сенс певному факту. Саме тому потрібно наголосити, що семіологічна філософія критикує Декартово-Кантове уявлення про раціональний суб'єкт, яке інтерпретує людину у вигляді вільної, автономної і моральної істоти, здібної до прозорого пізнання. Вона заявляє, що справжній центр людської самості зовсім не там, де його розташувала попередня гуманістична традиція; він є «вторинним», завуальованим мовною системою, яка не тільки впливає на суб'єкт, але й перетворює його. Характеризуючи цю обставину, М.Фуко, наприклад, цілком справедливо заявляє: «Взагалі, мова йде про те, щоб відправитися на пошуки іншої критичної філософії - не тієї, що визначає умови і межі знання об'єкта, але умови й безмежні можливості перетворення суб'єкта» (Фуко М., 2007, с. 573). Іншими словами, семіологічна філософія робить спробу розмістити суб'єкт в історичному контексті структурованих на кшталт мови практик i процесів, які постійно його змінюють. Вона вимагає відійти від «фактів досвіду», що приймаються позитивістською філософією за еталон будь-яких пошуків істини й концептуально проголошує необхідність писати історію «актів істини», під якими розуміє впорядковані процедури «прив'язування» суб'єкта до істини, своєрідні ритуалізовані дії, за допомогою яких будь-який суб'єкт фіксує власне співвідношення з будь-якою істиною. Тобто тут треба казати, скоріше, не про пізнавальну свободу, активність і автономність суб'єкта, а про його «гамівну оболонку», в яку суб' єкт потрапляє завдяки впливу на нього концептуальних настанов мовної системи.

3 іншого боку, суттєвих трансформацій набуває й кореспондентна концепція істини, яка традиційно тлумачиться як відповідність знання про дійсність самої дійсності. У контексті такого розуміння істинного знання повинна споглядатись не-суперечливість будь-якого дискурсу, яка буде спричиняти його зв'язність. Втім, структуралістські концепції заявляють про те, що все, що є насправді, є у мові (langue), і немає ніякої реальності, що відображалася б у мовленні (parole). Тому, сенс істини у дискурсі нібито розмивається, долаючи тим самим уявлення про будь-яку відповідність, а феноменологічні принципи дослідження замінюються на семіологічні.

Щоб переконатися в останньому, достатньо пригадати сутність принципу феноменологічної редукції, тобто звільнення свідомості від будь-якої природної установки: дістатися самої речі можна тільки внаслідок позбавлення всіх іiі предикатів, що приписуються наукою, традицією або вжитком, та описати ï такою, як вона є. Втім, річ можна позбавити всіх предикатів, окрім 
одного: існування. Отже, феноменолог завжди діє у контексті модерної метафізичної традиції: він має описати те, що є даним у досвіді, і нічого іншого. В той же час у семіолога завжди є можливість для філософських симуляцій: він констатує, що речі можна описати висловленнями за суб'єктно-предикативною формою. Причому вимога описувати за допомогою мовлення (parole) речі такими, які вони є, стає цілком легітимною. Тут досліджується мова (langage) висловлень, тобто предметом дослідження постає не річ, а мовна даність. «Щоб описати конституцію нашого досвіду, - пише О. Йосипенко, - ми, таким чином, маємо повернутися до нашої мови, а не до інтенціональних операцій свідомості» Йосипенко, 2012, с. 103).

Окрім антиметафізичної і антисуб'єктної настанови, характерною ознакою семіологічної філософії є iï антиісторична направленість, яка також запозичена зі структурної лінгвістики з їі лінгвістичною концептуальністю. Йдеться про те, що семіологи головну увагу приділяють дослідженню синхронічного виміру мови, чим закладають примат своєрідного «статичного» аналізу корпусу наук, історії та типології культури взагалі. Цей аналіз дозволяє виявити устрій формального наукового апарату, залишаючи поза кутом зору власне механізм становлення наук та історичний перехід від одного типу культури до іншого. Наприклад, симуляційна концепція «структурної епістемології» М.Фуко спричинила висновок про існування т. зв. «мертвого часу», яким поділяються між собою різні історичні епохи. Синхронічний зріз наук у контексті кожної епістеми обгрунтовується комплексом формальних умов, що складають можливості для наукового розвитку. Втім, перехід від епістеми Ренесансу до класики та від класики до сучасності Мішелем Фуко та його послідовниками аж ніяк не обгрунтовується. Для подолання безодні, що поділяє епістеми у часі, дослідник лише відшуковує низку апріорних мислительних прийомів (чи «висловлень»), що уможливлюють ту чи іншу науку або культурну особливість у контексті епістеми, та прагне зв'язати їх з історією. І цей шлях дослідження, на наш погляд, є цілком виваженим у контексті структуралізму: не суще має структуру, а певний стан сущого, подія, яка виражається висловленням 3 предикативною структурою. Отже, «у випадку семіологічної філософії ми маємо досить рідкісний приклад впливу наукового дослідження на філософську рефлексію... Лінгвістичний структуралізм у післявоєнній Франції поширився через антропологію, оскільки його методологія (передусім опозиція синхронічної та діахронічної лінгвістики) давала досліднику первісних культур змогу уникнути примусів історичного підходу і замінити часову домінанту в їхньому розгляді на просторову. Структуралістський погляд на культури, не затьмарений ілюзіями щодо «сенсу» або «уроків» історії $\epsilon$, фактично, просторовим поглядом... Це також сприяло переорієнтації філософських рефлексій тієї доби від теми діалектики 3 iі фігурами суперечності й тотожності, чия гра мала забезпечити вищу ідентичність суб'єкта та його історії, до теми відмінності, яка не зводиться до суперечності та мала помислити інше, не зводячи його до того самого» (Йосипенко, 2012, с. 107-108). 
Діахронічний вимір дослідження епістем у симуляційній концепції М.Фуко зводить нанівець загальновизнану у модерній філософії впевненість у неперервності та однонаправленості історичного процесу. Навпаки, Фукіанський проект базується на ідеї «розсіювання» історії на розмаїття історій культурних періодів. Кожному з цих періодів притаманні власні синхронічні мовні особливості, які, відповідно, формують специфічні правила ведення дискурсу, а отже, своє уявлення про істину, що робить цей дискурс зв'язним. Причому стан мови попередньої епістеми у його співвіднесенні з мовним станом іншої епістеми тут як раз i визначає діахронічний напрямок дослідження. Але ніякої єдиної, універсальної істини, яка б вийшла за межі епістем та спричинила їх зв'язок, не існує й не може існувати, оскільки, за впевненістю Фуко, зміна епістем не підкоряється жодній необхідності. Тим самим долається філософська традиція істини, що мала розвиток від Платона до Гуссерля.

Тим не менш, діахронічний вимір дослідження епістем Мішелем Фуко запозичений з концепції «еволюції мовних структур», наведеної Р.Якобсоном у специфічному розділі структурної лінгвістики, який має назву «структурна фонологія»: зміна епістем здійснюється за принципом зміни фонем - одиниць фонології, що не мають власного значення i отримують його лише у фонетичній системі мови. Ця модифікована екстраполяція методологічного апарату структурної лінгвістики у галузь семіологічної філософії постала можливою завдяки низці факторів. По-перше, сам Р.Якобсон обгрунтував можливості застосування фонології не тільки в контексті «наук про мову», але й у поетиці і психології. По-друге, наявність універсальних понять у іiі концептуальному апараті, які випливали з властивостей довільності знака та його незалежності від суб'єкта мовлення, дуже швидко переконали М.Фуко у тому, що шлях оздоровлення філософії лежить через реформу її мови.

\section{СПИСОК ВИКОРИСТАНИХ ДЖЕРЕЛ}

Cercle linguistique de Prague, «Theses»// Travaux du Cercle linguistique de Prague. - 1929. Descombes V. Grammaire d'objets en tous genres / V. Descombes. - Paris: Minuit, 1983.

Husserl E. Ideen $\mathrm{zu}$ einer reinen Phanomenologie und phanomenologischen Philosophie. Erstes Buch. Allgemeine Einfuhrung in die reine Phanomenologie / E. Husserl // Jahrbuch fur Philosophie und phanomenologische Forchung. - Halle u. d. S. Max Niemeyer, 1913. $323 \mathrm{p}$.

Jakobson R. Structure of language in its mathematical aspects / R. Jakobson // Proceedings of Symposia in Applied mathematics. -1961. - Vol. XII. - P. 245-252.

Whal F. La philosophie entre l'apres du structuralisme / F. Whal // Qu'est-ce que le structuralisme? - P.: Seuil, 1968.

Иванов В. В. Лингвистический путь Романа Якобсона / В. В. Иванов // Избранные работы / Р. О. Якобсон. - М.: Прогресс, 1985. - С. 5-29.

Йосипенко О. М. Від мови філософії до філософії мови. Проблема мови у французькій філософії другої половини XX - початку XXI століть / О. М. Йосипенко. - К.: Український центр духовної культури, 2012. - 479 с.

Соссюр Ф. де. Заметки по общей лингвистике / Ф. де Соссюр. - М. : Прогресс, 1990. - 280 с. 
Фуко М. Герменевтика субъекта. Курс лекций, прочитанных в Колледже де Франс в 19811982 учебном году / М. Фуко ; пер. с фр. А.Г. Погоняйло. - СПб. : Наука, 2007. $677 \mathrm{c}$.

Холенштайн Э. Якобсон и Гуссерль / Э. Холенштайн // Логос : философско-литературный журнал. - 1996. - № 7. - С. 7-37.

Эко У. Отстутствующая структура. Введение в семиологию / У. Эко. - М. : Петрополис, 1998. -432 c.

Эрлих В. Русский формализм: история и теория / В. Эрлих. - СПб. : Академический проект, 1996. -352 c.

Якобсон Р. Вопросы поэтики / Р. Якобсон // Работы по поэтике / Р. Якобсон. - М. : Прогресс, 1987. - С. 80-98.

Якобсон Р. Лингвистика в ее отношении к другим наукам / Р. Якобсон // Избранные работы : пер. с англ., нем., фр. / Р. Якобсон. - М. : Прогресс, 1985. - С. 369-420.

Якобсон Р. Лингвистика и поэтика / Р. Якобсон // Структурализм: «за» и «против» : сб. ст. / под ред. Е. Я. Басина и М. Я. Полякова. - М. : Прогресс, 1975. - С. 193-230.

Якобсон Р. Принципы исторической фонологии / Р. Якобсон // Избранные работы : пер. с англ., нем., фр. / Р. Якобсон ; сост. и общ. ред. В. А. Звегинцева ; предисл. В. В. Иванова. - М. : Прогресс, 1985. - С. 116-132.

Якобсон Р. Ретроспективный обзор работ по теории стиха / Р. Якобсон // Избранные работы : пер. с англ., нем., фр. / Р. Якобсон ; сост. и общ. ред. В. А. Звегинцева ; предисл. В. В. Иванова. - М. : Прогресс, 1985. - С. 239-269.

Якобсон Р. Речевая коммуникация / Р. Якобсон // Избранные работы : пер. с англ., нем., фр. / Р. Якобсон. - М. : Прогресс, 1985. - С. 306-318.

Якобсон Р. Тексты. Документы. Исследования / Р. Якобсон. - М. : Российский гос. гум. ун-т, 1999. $-920 \mathrm{c}$.

ВЛАДИМИР ПЕТРУШОВ

доктор философских наук, професор,

Украинский государственный университет железнодорожного транспорта (2. Харьков, Украина)

ORCID: 0000-0003-3279-2180

ВИТАЛИЙ ПАВЛОВ

кандидат философских наук, доиент,

Украинский государственный университет железнодорожного транспорта

(2. Харьков, Украина)

\section{ОТ СТРУКТУРНОЙ ЛИНГВИСТИКИ К СЕМИОЛОГИЧЕСКОЙ ФИЛОСОФИИ: ИСТОРИКО-ФИЛОСОФСКИЙ АНАЛИЗ}

В статье показана эволюция взглядов относительно истолкования языка как универсального метода, который так или иначе влияет на философский дискурс. Отмечено, что уже в недрах структурной лингвистики (Ф.де Соссюр, Р.Якобсон и др.) сформировался семиологический подход исследования языка, которое заложило условия для преодоления методологического субъективизма предыдущей науки и философии. Подчеркнуто, что языковая структура - это не просто объяснительная конструкция, она, выделив в себе множество определенных метафизических оппозиций, стремится преодолеть их и выйти за пределы эмпирических исследований. При ее помощи возникает возможность рассматривать психические и духовные феномены как такие, что не выводятся каузально из физиологических процессов, а наоборот, «внутренне запрограммированные», то есть создают определенные структуры (Е.Гуссерль), что порождает возникновение разнообразия грандиозных спекулятивных теорий в блоке гуманитарных наук, которые стремились к научной строгости и обновлении 
собственной структурной лингвистики закладывая тем самым основания семиологической философии. Дана характеристика особенностям семиологической философии, а именно, зарождение диадичных и триадичных моделей структуралистов и постструктуралистов с их репрезентативностью временно-пространственных оппозиций, невозможность хронологической разрозненности структурализма и постструктурализма и их соединение в единый способ философствования; предложение концептуального аппарата поиску новой формы рациональности (т.наз. «формальной рациональности), которая допускает множество актуализаций в «вербальном психоанализе» (Ж.Лакан), литературоведении (Р.Барт), «структурной эпистемологии» М.Фуко, антиметафизических демаршах Ж.Дерида и Ж.Ф.Лиотара и попытках «симулякризации действительности» Ж.Бодрийяра.

Ключевые слова: говорение, языковая структура, структурная лингвистика, семиологическая философия, семиологический знак, знаковая система, метафизическая оппозиция.

VOLODYMYR PETRUSHOV Doctor of Philosophical Sciences, Professor, Ukrainian State University of Railway Transport (Kharkiv, Ukraine) ORCID: 0000-0003-3279-2180

VITALII PAVLOV

PhD in Philosophy, Associate Professor Ukrainian State University of Railway Transport (Kharkiv, Ukraine)

\section{FROM STRUCTURAL LINGUISTICS TO SEMIO LOGICAL PHILOSOPHY: HISTORICAL AND PHILOSOPHICAL ANALYSIS}

The article shows the evolution of views on the interpretation of language, as a universal method, which in some way influences philosophical discourse. It has been outlined that semiotic approach to the study of language was formed already in the depths of structural linguistics (F.D. Sosyur, R. Jacobson, etc.), which laid the groundwork for overcoming the methodological subjectivism of prior science and philosophy. It is emphasized that the linguistic structure is not just an explanatory construct; it, having isolated a set of certain metaphysical opposition, seeks to overcome them and go beyond the limits of empirical research. With its help it is possible to consider mental and spiritual phenomena as such that are not deduced causally from the physiological processes, but rather "internally programmed", that means that they create certain structures (E. Husserl), which causes the emergence of a variety of spectacular theories in the block of humanities, who sought scientific rigor and renovation of their own methodological reflection, appealing to the systematic and objective approach to structural linguistics, thus laying the foundations of semio logical philosophy. Characterized by the peculiarities of semiotic philosophy, namely: the origin of dyadic and triadic models of structuralists and post-structuralists with their representativeness of timespace opposition; the impossibility of chronological distinction between structuralism and poststructuralism and their combination in a single way of philosophizing; offering a conceptual apparatus for finding a new form of rationality (the so-called "formal rationality"), which implies a multitude of actualizations in "verbal psychoanalysis" (J. Lakan), literary criticism (R. Bart), "structural epistemology" M. Fuko, anti-metaphysical demarches J.Derid and J.F.Liotara and attempts to "simulacrizationof reality" by J. Bodriyar.

Key words: language, speech, language structure, structural linguistics, semio logical philosophy, semioological sign, sign system, metaphysical opposition.

\section{REFERENCES}

Cercle linguistique de Prague, «Theses» (1929). Travaux du Cercle linguistique de Prague. P. 7-29. 
Descombes V. (1983). Grammaire dobjets en tous genres. Paris : Minuit.

Husserl E. (1913). Ideen zu einer reinen Phanomenologie und phanomenologischen Philosophie. Erstes Buch. Allgemeine Einfuhrung in die reine Phanomenologie. Halle u. d. S. Max Niemeyer. 323 p.

Jakobson R. (1961). Structure of language in its mathematical aspects / R. Jakobson // Proceedings of Symposia in Applied mathematics.Vol. XII. - P. 245-252.

Whal F. (1968). La philosophie entre lapres du structuralisme / F. Whal. Quest-ce que le structuralisme? - P.: Seuil.

Yvanov V. V. (1985). Lynhvystycheskyi put Romana Yakobsona. M.: Prohress. S. 5-29.

Yosypenko O. M. (2012). Vid movy filosofii do filosofii movy. Problema movy u frantsuzkii filosofii druhoi polovyny $\mathrm{KhKh}$ - pochatku KhKhI stolit. K.: Ukrainskyi tsentr dukhovnoi kultury. $479 \mathrm{~s}$.

Sossiur F. de. (1990). Zametky po obshchei lynhvystyke. - M. : Prohress.280 s.

Fuko M. (2007). Hermenevtyka subъekta. Kurs lektsyi, prochytannykh v Kolledzhe de Frans v 1981-1982 uchebnom hodu. - SPb.: Nauka. 677 s.

Kholenshtain.(1996). Yakobson y Husserl. Lohos : fylosofsko-lyteraturnyi zhurnal. № 7. S. 7-37.

Eko U. (1998). Ststutstvuiushchaia struktura. Vvedenye v semyolohyiu. M. : Petropolys. 432 s.

Erlykh V. (1996). Russkyi formalyzm: ystoryia y teoryia. SPb.: Akademycheskyi proekt. $352 \mathrm{~s}$.

Yakobson R. (1987). Voprosy poetyky. M. : Prohress. S. 80-98.

Yakobson R. (1985). Lynhvystyka v ee otnoshenyy k druhym naukam. M. : Prohress. S. 369-420.

Yakobson R. (1975). Lynhvystyka y poэtyka. M.: Prohress. S. 193-230.

Yakobson R. (1985). Pryntsypy ystorycheskoi fonolohyy. M.: Prohress, 1985. S. 116-132.

Yakobson R. (1985). Retrospektyvnыi obzor rabot po teoryy stykha. M. : Prohress. S. 239-269.

Yakobson R. (1985). Rechevaia kommunykatsyia. M. : Prohress. S. 306-318.

Yakobson R. (1999). Teksty. Dokumenty. Yssledovanyia. M.: Rossyiskyi hos. hum. un-t. 920 s.

\section{Надійшла до редакції 13.05.2019}

